\title{
Customer Loyalty in Mobile Banking: Evaluation of Perceived Risk, Relative Advantages, and Usability Factors
}

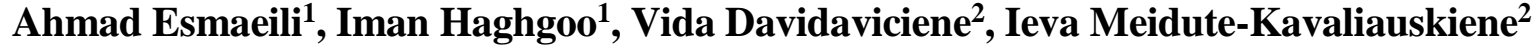 \\ ${ }^{1}$ Allameh Tabataba'i University \\ 14348-63111, Tehran, Iran \\ E-mail.esmaeili921@atu.ac.ir; imanhaghgoo@gmail.com \\ ${ }^{2}$ Vilnius Gediminas Technical University \\ Sauletekio al. 11, LT-10223 Vilnius, Lithuania \\ E-mail.vida.davidaviciene@vgtu.lt; ieva.meidutekavaliauskiene@vgtu.lt
}

cross $^{\text {ref }}$ http://dx.doi.org/10.5755/j01.ee.32.1.25286

\begin{abstract}
Information and communications technologies promote change in the service sector, and the banking sector is not an exception. Finding what factors impact consumer satisfaction with service and lead to loyalty is invariably important for business. However, it is important to begin with evaluating the aspects that are specific to the market and service. The purpose of this study was to investigate the factors affecting customer loyalty in Mobile Banking. Following the model designed by the researchers, consideration was given to mediator variables of satisfaction, trust, and customer service to examine how factors such as perceived risk, relative advantages, and usability affect customer loyalty. In this study, customers of an Iranian bank (Shahr Bank) based in the city of Tehran constituted the statistical population. The descriptive survey method was used on a sample that was selected through a cluster-convenience method and included 411 Shahr Bank's customers resident in the east, west, north, south, and centre of the city of Tehran. Structural Equation Modelling (SEM) test and the LISREL 8.8 software were used to analyse the data and to determine what role each factor plays on loyalty. The results showed that such factors as relative advantages, satisfaction, and trust have the most significant impact on customer loyalty. However, the effect of usability on customer service was not confirmed. Furthermore, it was identified that perceived risk has a negative impact on loyalty.
\end{abstract}

Keywords: Electronic Banking (E-Banking); Mobile Banking; Technology Acceptance; Loyalty.

\section{Introduction}

The reach and evolution of the internet and information technology have affected and changed our daily life (Laukkanen, 2016; Puriwat \& Tripopsakul, 2017; Rizwan, Vveinhardt, \& Streimikiene, 2017; Raudeliuniene et al., 2018; Mladenovic \& Krajina, 2020). Over the recent decade, electronic commerce and IT have had a consistent effect on the business environment of the world (Davidaviciene, Pabedinskaite, and Davidavicius 2017). In addition, various applications and technologies have started to place extra emphasis on mobile commerce, mobile computing, and wireless web. The banking industry has also been affected by these influences. The increasingly competitive financial environment has prompted banks to search for new channels to deliver services to their customers (Lin et al., 2018; van Esterik-Plasmeijer \& van Raaij 2017; PalamidovskaSterjadovska \& Ciunova-Shuleska 2017). In this context, mobile banking is becoming a necessary channel of distribution (Shaikh \& Karjaluoto 2015). It means that banks can provide various products and services to their customers. For more than 200 years, banks have offered banking services to their customers through their network of branches. However, the advent of different types of technology has changed the way financial services are provided to customers. Banks have benefited from electronic banking (e-banking) services by offering lower transaction costs, 24-hour services, and increased efficiency in the banking process.
The amazing development of the mobile sector across the world has created a unique substitute for banking via the provision of financial services with mobile phones. Mobile banking (m-banking) applications are a partially new development that has been receiving increasing popularity since they were introduced to the banking sector. Mobile banking is among the latest in a series of new mobile technological wonders. Although technology like automated teller machines (ATMs), telephones, and internet banking offers effective delivery channels for traditional banking products, mobile banking channels have been established by retail and microfinance banks in many developed and developing countries and have had significant effects on the market (Shaikh \& Karjaluoto, 2015; Vo et al., 2017; Arcand et al., 2017; Jia et al., 2018; Karimi et al., 2018).

Mobile technology plays an increasingly critical role in our daily life. The growing number of mobile device users marks a noticeable growth rate of m-banking (Sujeong, 2018; Puriwat \& Tripopsakul, 2017). The development of ebanking services in the banking sector has led to changes in the structure of distribution channels. This new channel of mbanking has significantly reduced the costs of the banking sector. By offering e-banking services, banks can benefit from cost savings, reduce the number of branches and personnel, and in turn increase their profitability. Moreover, m-banking enables customers to use their mobile devices to access information and use services, such as balance check, 
money transfer, bill payment, and financial management anytime, anywhere (Zhou, 2018).

Shahr Bank, a bank based in Iran, uses e-banking systems, including Automated Teller Machines (ATMs), internet banking and mobile banking, and offers different services to its customers.

This study aims to investigate the factors affecting customer loyalty in the context of m-banking use by Shahr Bank's customers. These factors eventually contribute to the implementation of strategic programs in the field of ecommerce by bank managers. Shahr Bank has not acted in the same way as its competitors. The technology growth rate has affected the competitive market of the banks and the way customers perceive them. Therefore, being a new phenomenon in the banking sector of Iran, m-banking can offer a significant and substantial competitive advantage. Consequently, Shahr Bank can gain plentiful benefits from this competitive advantage in accordance with its vision and policies. Moreover, these studies discussed below can contribute to the bank's strategies to attract and retain its customers.

\section{Related Literature}

E-banking is a banking service that was first used in the US in 1995. It quickly spread through other developed countries and subsequently through developing countries (Wan, Luk \& Chow, 2005). There have been numerous definitions of e-banking, including the following:

- With the help of mobile banking which is an evolved version of electronic banking, consumers can make financial transactions using mobile devices (Mohammadi, 2015).

- Providing customers with access to banking services by secure intermediaries and without the physical presence (Daniela et al., 2004)

- Customers use the Internet to organize, test, or implement changes to their bank accounts or make investments in banks to offer banking operations and services (Nexhmi, 2004).

M-banking is a wireless communications channel created to generate value through customer banking transactions. Recently, providing financial and banking services via mobile phones has been of utmost interest in the area of banking services. The field has witnessed significant progress over a very short time, which promises that this new way of ebanking will be widespread in the future, similarly to the experience of most countries in the area of banking and financial services (Laukkanen, 2005).

Mokhtar et al. (2017) created and analysed a model with the use of a number of constructs, namely ubiquitous finance control (UFC), social influence, perceived trust with mobile banking adoption, and customer satisfaction to evaluate customer loyalty. Data collected from 263 users of mobile banking in Saudi Arabia were compared with the proposed model applying the structural equation modelling technique. Low and et al. (2017) examined the main components of customer loyalty involved in mobile banking. Our results revealed that perceived convenience, subjective norms, and perceived usefulness had positive significant effects on customer loyalty. The findings have some significant implications, which can be used by policymakers to comprehend customer loyalty in the mobile banking sector of Malaysia. The results carry important implications for policymakers in terms of understanding customer loyalty in the Malaysian mobile banking sector.

Liebana Cabanillas et al. (2017) performed empirical research the main purpose of which was to identify the variables that influence the loyalty of the users of mobile banking, to segment consumers, and to explain the causes. To collect data, a self-administered online survey was employed which was later evaluated using partial least squares (PLS) analysis. The PLS-prediction-oriented segmentation (PLSPOS) methodology showed unobserved heterogeneity. In addition, the most important variables in each segment were determined using an importance-performance map analysis. This general model indicates that present banking utilization and satisfaction have a positive effect on customer loyalty. Puriwat and Tripopsakul (2017) examined the impact of the quality of e-service on customer satisfaction and customer loyalty to mobile banking services among the Thai users of mobile banking in 2015. In this research, SEM was utilized to assess the influence of the quality of e-services on customer loyalty and satisfaction. The results of the latter study revealed that in general, e-service quality has a great impact on customer loyalty and satisfaction. Trust, reliability, and finally responsiveness were found as the important dimensions that explain e-service quality. Based on the symbolic value theory and brand equity theory, Sun, Wang, and Wang (2015) offered a study model to display the relation between brand equity, technology leadership, customer loyalty, and the mediating role of the need for uniqueness. A survey was carried out among the users of two mobile banking service providers to perform an empirical examination of the recommended research hypotheses and model. The findings revealed that technology leadership has a positive influence on brand equity which consequently has a positive impact on customer loyalty. Furthermore, the results indicated that the need for uniqueness improves the relation between customer loyalty and brand equity and also strengthens the relationship between brand equity and technology leadership.

The results of Alonso-Dos-Santos et al. (2020) showed that there were relationships between quality and satisfaction, satisfaction and loyalty, trust and loyalty, perceived risk and trust, as well as perceived risk and mobile banking usage. The relationship between loyalty and the use of mobile banking was observed as the most significant.

Along with satisfaction factors, scholars have investigated aspects of dissatisfaction in e-services (Davidaviciene et al., 2019). These aspects should also be considered as critical in research methodology.

Sabaityte et al. (2019) emphasize the importance of considering the stages of an electronic consumer's journey and defining the most relevant communications tools and applications in each stage that would lead to higher user satisfaction.

Aldas-Monzano et al. (2011) analyse the roles of satisfaction, trust, frequency of use, and perceived. Evaluating their effect on the relationship between satisfaction and loyalty is highly important.

Shankar and Jebarajakirthy (2019) draw a parallel in the evaluation of customer loyalty factors in e-banking. Findings suggest that e-banking consumers give preference to convenience, reliability, safety, security, and customer service, but not to website design. 
In his study, Mohammadi (2015) explored barriers, usability mediating role, the moderating impacts of personal innovativeness, and subjective norms concerning the attitudes of Iranian consumers toward mobile banking. According to the data collected from consumers by a survey, structural equation modeling (SEM) and path analysis were applied to examine the research model. The findings demonstrated "system compatibility" as the leading factor influencing the attitudes of users about using mobile banking. Moreover, "Resistance" had a significant negative impact on the simplicity of application and usefulness. "Perceived usefulness" was shown to mediate the relationship between the simplicity of application and the attitudes of users.

Kuhandawa and Wijayanayake (2014) conducted a case study in a public bank in Sri Lanka, studying the impact of m-banking services on customer satisfaction. They focused on identifying the factors that affect customer satisfaction with m-banking services. The main variables in this study were usefulness, ease of use, relative advantages, risk perception, user lifestyle, and current needs. All the hypotheses were confirmed, and it was found that usefulness, lifestyle, relative advantages, ease of use, and perceived risk had the most to the least significant influence on customer satisfaction respectively.

Sepandavand (2013) conducted a study with the title "Factors affecting the interests of customers to use mobile banking at Eghtesad Novin Bank (an Iranian bank)". This was an applied study employing a descriptive survey to collect data. In the study, the researchers investigated the factors influencing customers' tendency to use m-banking. They employed a model based on the theory of acceptance. Structural equation modelling and Pearson correlation coefficient were also used to test the research hypotheses. All hypotheses were confirmed.

Shankar et al. (2020) analyse the electronic word of mouth (e-WOM) as another critical success factor of ebanking since it has been proved previously that e-WOM plays a crucial role in the e-commerce performance (quality, valence, consistency, and volume were considered to have been triggered by e-WOM).

Torabi (2009) examined the factors affecting the use of m-banking electronic services by customers. According to the results, compatibility variables, cost of use, functionality, and usefulness were among the characteristics of m-banking technology and the most critical factors affecting the use of m-banking services. On the other hand, the complexity and perceived risk of using m-banking services had little effect. Psychological characteristics included risk-taking and pro-change mentality and were some of the factors affecting the use of m-banking services. However, opinion leadership did not have much impact on the use of m-banking services. Furthermore, the element of gender in the use of m-banking services was an influential demographic factor, while marital status did not have any impact on the use of this type of service.

In a study titled "Experimental investigation of initial trust in M-BANKING", Zhou (2011) examined the effect of trust on m-banking user's acceptance. The results showed that the main factors affecting initial trust are structural guarantee and information quality. On the other hand, the information quality and system quality significantly affected perceived usefulness. The initial trust affected perceived usefulness, and both were used as factors to predict the tendency to use m-banking.

\section{Research Hypotheses and Conceptual Model}

In this study, effects on customer loyalty were evaluated, including the effect of the usability variable along with the intermediary roles of customer service, trust, and satisfaction. Additionally, the impact on customer loyalty was examined in terms of the variables of perceived risk and relative advantages.

Usability is known as the effort needed when utilizing a computer system or mobile phone for banking and depends on different aspects, including the ability to use the effective learning of system management, simplicity of maintaining the major functions, level of productivity designed by the user interface, degree of error avoidance, and general satisfaction of user with manageability (Nielsen \& Hackos, 1993). Usability higher levels are related to usability management (improving usability) by diminishing difficulty level (Davis, 1989). Consequently, usability is conventionally regarded as one of the main factors in the prediction of inclination for any given system (Davis 1989; Flavian, Guinaliu, \& Gurrea, 2006; Teo 2006). Recently, the effect of usability on satisfaction rate and loyalty in the field of online banking have been assessed in some studies. Perceived usability was found to have a positive influence on customer satisfaction and the preferences of a company for future interactions (Casalo et al., 2008).

Loyalty is considered to be a customer's intention to show preference to a product or a business over other products or businesses for specific needs. A loyal customer is someone who frequently buys products and services from one seller, and persistently recommends those to all their relatives and friends communicating a positive attitude. Therefore, a $5 \%$ increase in customer loyalty leads to a 25 to 85 per cent rise in the company's earnings. This rate is called the cost of loyalty. That is why traders pay attention to the most established relationships within their business relationships (Mohammadi, 2015).

Trust is one of the necessary components of the commitment-trust theory. Morgan and Hunt (1994) demonstrated in this theory that trust is the centre of a successful relationship marketing. They suggested that there was trust "[i]f one has trust in the integrity and reliability of the exchange (trade)". Distrust could affect consumers' attitudes toward banks and financial institutions. It could have an extreme effect on customers' attitudes to new forms of service delivery via the internet. Research studies revealed a strong correlation between trust in online channels and the reception of e-banking (Kim and Prabhakar, 2000). Hence, Hypothesis 1: Usability exerts a direct positive effect on customer trust in m-banking.

Customer service through online channels, such as mbanking, is considered as the services delivered to customers via call centres (i.e., phone, e-mail, etc.), especially concerning challenging conditions (Ganguli \& Roy, 2011). In an article, Bitner (1992) suggested that support services or remote services increase customer satisfaction and felt appeal when it comes to self-service organizations that employ very few staff but have high customer activity. The 
image of the company and the level of customer satisfaction are affected where there is not enough information from the service providers (Burgers et al. 2000). Hence, Hypothesis 2: Usability imposes a direct positive influence on customer service in m-banking.

Satisfaction is referred to a value judgment after selecting a specific purpose. It is mostly used as a part of the paradigm for approval and disapproval (Swan and Oliver 1989). Geyskens, Steenkamp, and Kumar (1999) recommended dividing the concept of satisfaction into two separate positions, including an influential and stable background of economic conditions (e.g., sales or obtained profit margins) and psychological variables (e.g., policy implementation partner or simplicity in relationships with given partners). Therefore, hypothesis 3 is that usability imposes a direct positive effect on the satisfaction of the customer with m-banking.

While research on the relationship between customer service and trust is in its infancy, there is valid evidence indicating the existence of a relationship between customer service and trust. In a study by Yeh and Lee (2009), it was found that customer service has an indirect effect on trust. Hence, Hypothesis 4: Customer service has a direct and positive impact on customer trust in m-banking. There is also strong scientific support for the impact of customer service on customer satisfaction in the relevant literature (Ganguli \& Roy, 2011; Ho \& Lin, 2010). Hence, Hypothesis 5: Customer service has a direct and positive impact on customer satisfaction with m-banking.

The related literature on $\mathrm{m}$-banking by Burrell and Morgan (1994) suggests that customer trust has a positive effect on loyalty. Hence, Hypothesis 6: Customer trust has a direct and positive impact on customer loyalty to m-banking.

In the marketing literature, it is revealed that higher levels of customer satisfaction lead to higher levels of individual loyalty among customers (Yoon and Kim 2000). In a study by Coker (2013), it was found that customer satisfaction has a positive effect on loyalty. Moreover, a study by Eid (2011) found that customer satisfaction is a direct antecedent of consumer loyalty. Hence, Hypothesis 7: Customer loyalty in m-banking has been shown to be directly and positively influenced by satisfaction. Perceived risk represents five risk aspects, namely performance risk, security risk, time risk, social risk, and financial risk. Lee
(2009) states that the five mentioned dimensions could be adapted for $\mathrm{m}$-banking as described here:

- Performance risk is the damage resulting from deficient or malfunctioning m-banking servers.

- The security risk refers to fraud and cheating attempts by hackers and the potential loss of security by the affected m-banking users.

- Time risk refers to the loss of time and any inconvenience that occurs due to delays in reception, payment, or navigation problems.

- Social risk suggests the possibility of resistance to the use of m-banking by friends, family, and colleagues.

- Financial risk is defined as the potential financial loss resulting from an error in transactions or the misuse of bank accounts.

In a study, Wu and Wang (2005) found that perceived risk has an impact on the adoption of m-banking. Therefore, Hypothesis 8: Perceived risk (time risk, performance risk, security risk, social risk, and financial risk) has an inverse and negative impact on customer loyalty to m-banking. Relative advantages represent the competitive benefits that are not possible for m-banking users to receive from other types of banking services. Pikkarainen et al. (2004) recommended that it is more likely that users accept mbanking in case they believe it has more advantages than other traditional banking channels, namely ATM or internet banking. Moreover, this entails the perceived cost and time. Perceived cost savings are the transaction costs related to $\mathrm{m}$ banking transactions, such as credit and bank commission. Perceived cost refers to the belief of a person concerning the costs of applying m-banking (Luarn \& Lin, 2005). This cost may include transaction costs in the form of bank fees, mobile network fees when using communications traffic (such as SMS or data), and the cost of mobile devices. Perceived time savings denote the time required to complete transactions somewhere. In a study, Lee (2009) found that time plays a significant role in the adoption of m-banking services by users.

Consequently, Hypothesis 9: Relative advantages (perceived cost savings, perceived time savings) have a direct and positive impact on customer loyalty to $\mathrm{m}$ banking. The conceptual model of this study is presented in Figure 1.

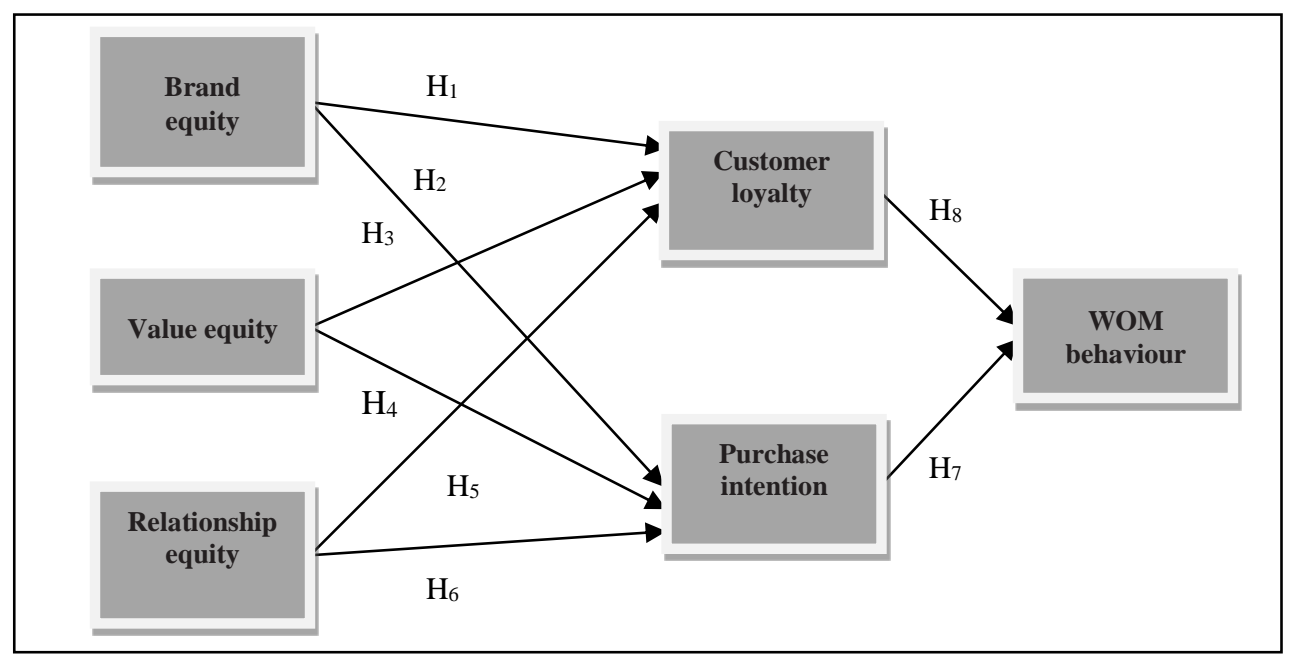

Figure 1. The Conceptual Model of the Study Derived from the Models by Thakur (2014) \& Kabir (2013) 


\section{Methodology}

This was an applied study and employed descriptive research methods. The statistical population was composed of all Shahr Bank's customers. The data collection began in November 2018 and ended in February 2019. In this study, out of 500 questionnaires distributed by e-mail through cluster sampling, 411 were returned to the researcher for data analysis and considered reliable samples. Accordingly, the sample size in this study was equal to 411 . In this case, the city of Tehran was divided into 5 regions (north, south, centre, west, and east). The bank branches were selected randomly from each region, and the questionnaires were distributed to the customers of these branches.

\section{Measurement Model}

In this research, 20 individuals out of the statistical population were selected at first to determine the reliability of the questionnaire. The questionnaires were administered; subsequently, the reliability was determined through Cronbach's alpha with a value of 0.89 . Consequently, it was concluded that the questionnaire had acceptable stability and reliability. Table 1 shows the indices, references, and Cronbach's alpha coefficient for each variable.

Table 1.

Cronbach's Alpha Test for the Reliability of Variables

\begin{tabular}{|c|c|c|c|c|}
\hline Concept & Index & Questions & Reference & Cronbach's alpha \\
\hline $\begin{array}{l}\text { Perceived } \\
\text { Risk }\end{array}$ & $\begin{array}{l}\text { Performance risk } \\
\text { Financial risk } \\
\text { Social risk } \\
\text { Time risk } \\
\text { Security risk }\end{array}$ & $15-24$ & Lee (2009) & 0.77 \\
\hline $\begin{array}{l}\text { Relative } \\
\text { advantages }\end{array}$ & $\begin{array}{l}\text { Perceived cost savings } \\
\text { Perceived time savings }\end{array}$ & $25-28$ & $\begin{array}{l}\text { Laurn \& Lin (2005) } \\
\text { Lee (2009) }\end{array}$ & 0.78 \\
\hline Usability & $\begin{array}{l}\text { Ease of use } \\
\text { Availability of information }\end{array}$ & $1-2$ & $\begin{array}{l}\text { Flavian, Guinaliu, and } \\
\text { Gurrea (2006) }\end{array}$ & 0.76 \\
\hline $\begin{array}{l}\text { Customer } \\
\text { Service }\end{array}$ & $\begin{array}{l}\text { Response time } \\
\text { Empathy with customer } \\
\text { Enough knowledge to solve problems }\end{array}$ & $3-5$ & Rafaeli et al. (2008) & 0.71 \\
\hline Satisfaction & $\begin{array}{l}\text { Satisfaction with user experience } \\
\text { Overall satisfaction } \\
\text { Satisfaction with service }\end{array}$ & $6-8$ & $\begin{array}{l}\text { Casalo et al. (2008) } \\
\text { Davis (1989) }\end{array}$ & 0.92 \\
\hline Trust & $\begin{array}{l}\text { Meeting obligations } \\
\text { Attention to users' interests } \\
\text { Good knowledge of customers }\end{array}$ & $9-11$ & Mukherjee \& Nath (2003) & 0.81 \\
\hline Loyalty & $\begin{array}{l}\text { Service use in the future } \\
\text { Future use forecast } \\
\text { Possibility of future use }\end{array}$ & $12-14$ & $\begin{array}{l}\text { Casalo et al (2008) } \\
\text { Davis (1989) }\end{array}$ & 0.76 \\
\hline \multicolumn{4}{|c|}{ Total Questionnaire } & 0.89 \\
\hline
\end{tabular}

Table 2 shows Pearson correlation coefficients for the relationship between latent variables in a mutual form. Number 1 is placed on the main diagonal of the matrix to show that each variable has a complete correlation with itself. The correlations are significant at the trust level of $99 \%$ (the significance level value is less than $1 \%$, and it is marked with ** symbols.) Some correlation coefficients are significant at the trust level of $95 \%$ (the significance level value is less than $5 \%$, and it is marked with *.)

Pearson Correlation Coefficients and Descriptive Reliability and Validity

\begin{tabular}{|c|l|c|c|c|c|c|c|c|}
\hline No. & \multicolumn{1}{|c|}{ Constructs } & $\mathbf{1}$ & $\mathbf{2}$ & $\mathbf{3}$ & $\mathbf{4}$ & $\mathbf{5}$ & $\mathbf{6}$ & $\mathbf{7}$ \\
\hline 1 & Customer loyalty & 1 & & & & & & \\
\hline 2 & Customer trust & 0.46 & 1 & & & & & \\
\hline 3 & Customer service & 0.53 & 0.63 & 1 & & & & \\
\hline 4 & Customer satisfaction & 0.51 & 0.79 & 0.96 & 1 & & & \\
\hline 5 & Relative advantages & 0.18 & 0.16 & 0.31 & 0.24 & 1 & & \\
\hline 6 & Perceived Risk & 0.74 & 0.24 & 0.48 & 0.38 & 0.25 & 1 & \\
\hline 7 & Usability & 0.49 & 0.48 & 0.94 & 0.75 & 0.33 & 0.51 & 1 \\
\hline AVE & 0.69 & 0.73 & 0.66 & 0.60 & 0.75 & 0.82 & 0.65 \\
\hline CR & 0.76 & 0.73 & 0.71 & 0.79 & 0.89 & 0.88 & 0.83 \\
\hline & MEAN & 3.45 & 3.01 & 2.89 & 4.01 & 2.78 & 3.25 & \\
\hline SD & 0.991 & 0.963 & 1.042 & 1.013 & 0.956 & 0.991 & 3.14 \\
\hline
\end{tabular}

*Coefficients are significant at a trust level of 99 percent. 
The positive coefficient indicates a direct and positive relationship between the two variables, while the negative coefficient shows a negative and significant relationship between the two variables. Table 2 also shows the explained average variance index and composite reliability. Moreover, to construct validity, which is used to examine the importance of selected indicators for measuring used constructs, discriminant validity is considered so that the indicators of each construct provide appropriate separation in terms of measurement compared with other constructs of the study. Essentially, each indicator only measures its construct, and their composition should be in such a way that all the constructs are well separated. Composite reliability (CR) index is used to evaluate the reliability of the questionnaire, and it is required to approve the higher reliability of these indices from the value of 0.7 . All of these coefficients are above 0.7 and are indicative of the reliability of the measurement instrument.

The two last columns of this Table present the descriptive indices. If the mean value is higher than 3 ; it can be said that the given variable has been evaluated above average by respondents. If the mean value obtained is lower than 3 , it can be concluded that the given variable has been evaluated below average. The results show an optimum satisfaction with all the variables in the study.

\section{Findings}

The LISREL software was used to test the hypotheses and to investigate the relationships between the elements of the model. The results of the analysis of the model are presented in Figure 2 and Figure 3 in the states of path coefficients and significance coefficients.

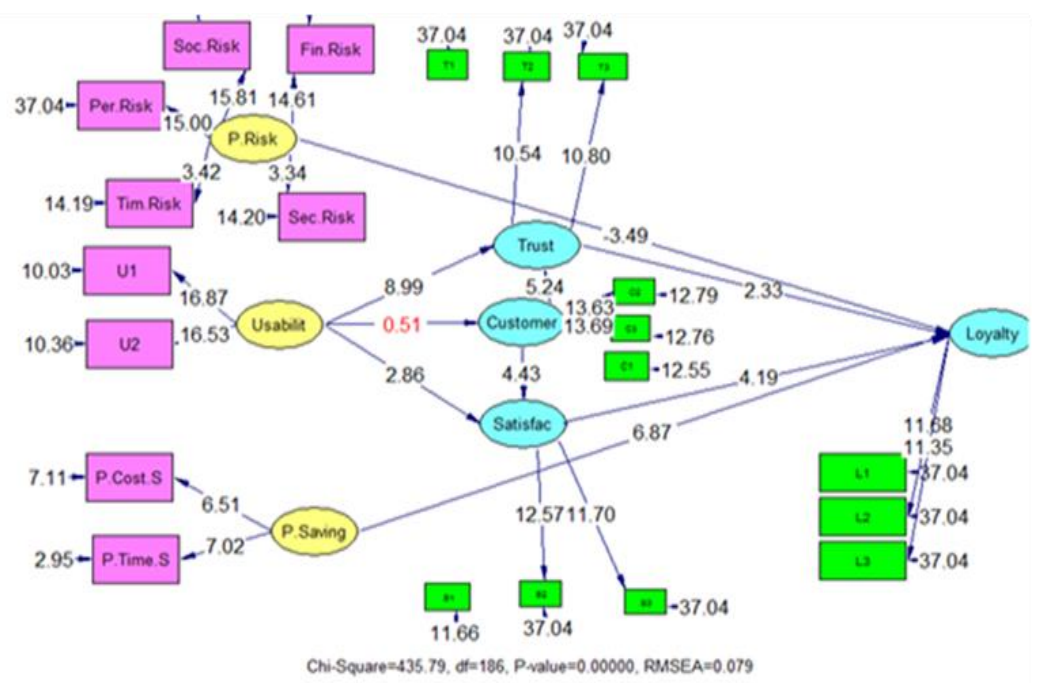

Figure 2. The Research Model: Significance of Coefficients (t-value)

Structural Equation Modelling (SEM) and LISREL 8.8 software were used to test the hypothesis. According to Table (3), demonstrates that usability had a positive significant relationship with a customer relationship with the path coefficient, t-statistic, and significance level of $0.56,8.99$, and 0.01 , respectively. Consequently, the first hypothesis was confirmed. Therefore, the first hypothesis was confirmed.
Regarding the second hypothesis, usability had a positive significant relationship with customer service with a t-statistic of 0.51 leading to the rejection of the second hypothesis. In the third hypothesis, usability was observed to have a positive significant relationship with customer satisfaction with the path coefficient, t-statistic, and significance level of $0.49,2.86$, and 0.01 , respectively. Therefore, the third hypothesis was confirmed.

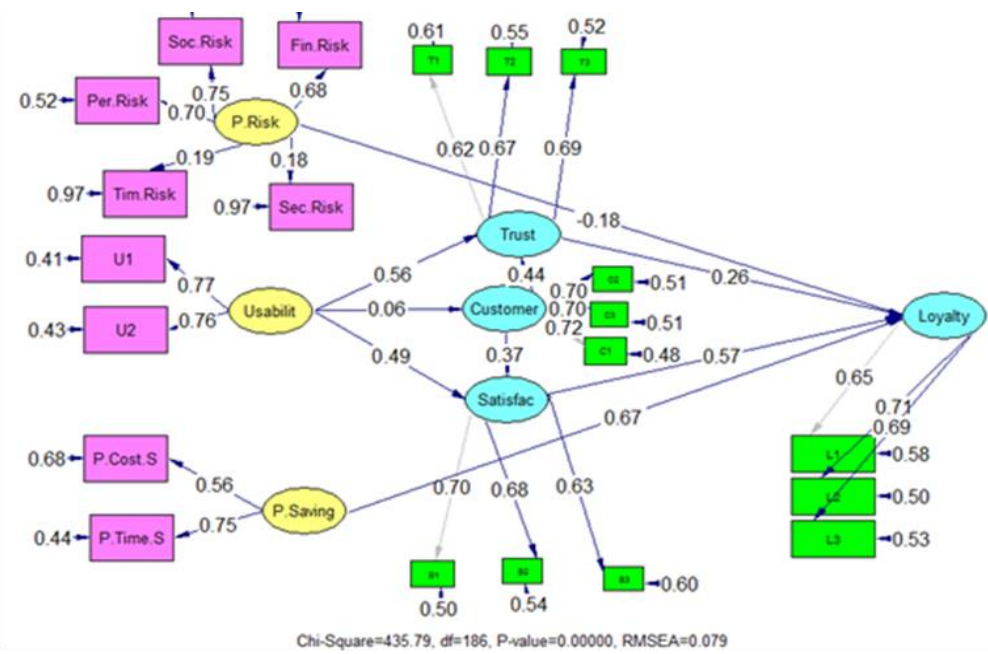

Figure 3. The Research Model: Estimating Path Coefficients 
Table 3 hypothesis was confirmed. In the ninth hypothesis, a

Summary of Research Hypotheses

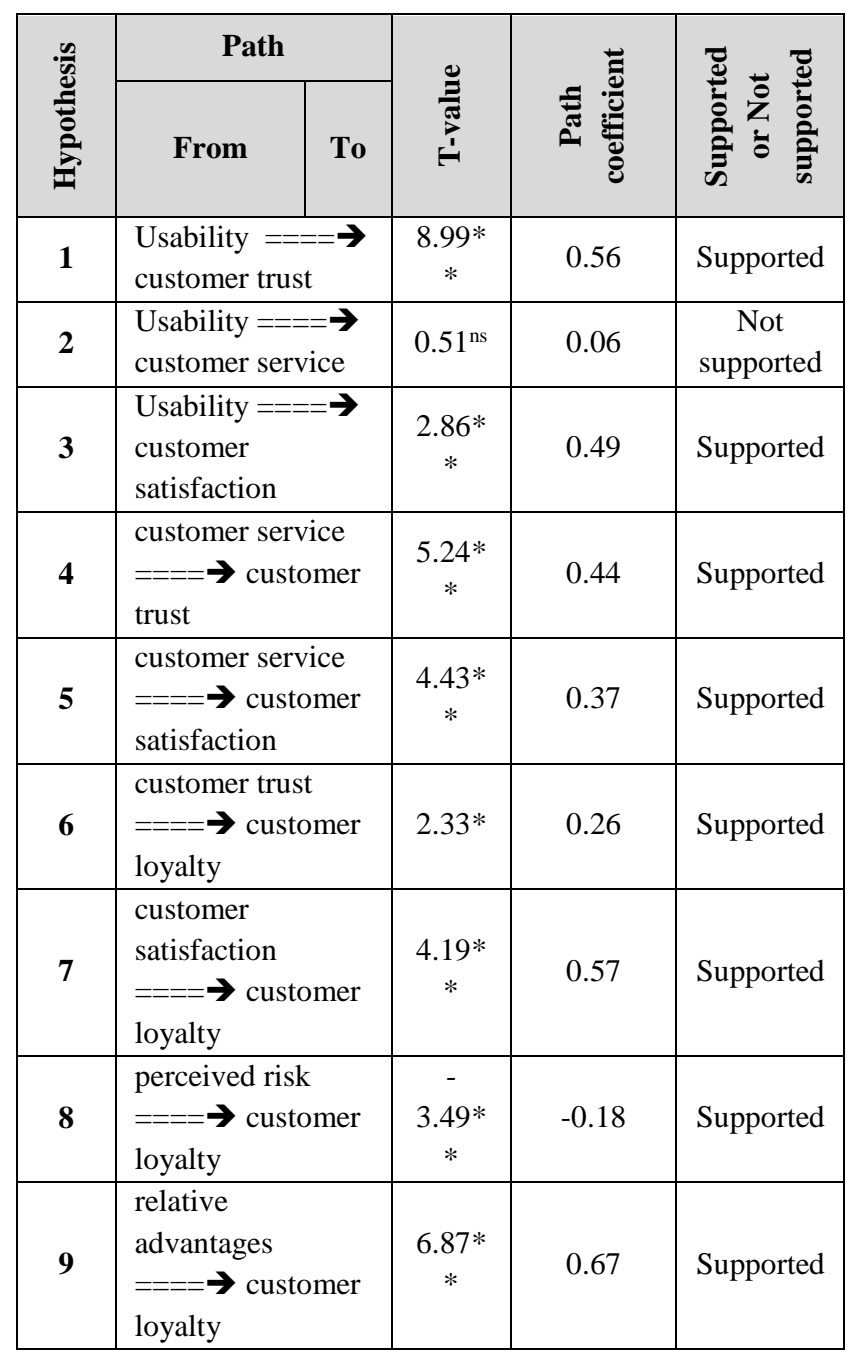

$n s=$ nonsense, $*=$ significant at the level of $0.05, * *=$ significant at the level of 0.01

According to the fourth hypothesis, there was a positive and significant relationship between customer service and customer trust with the path coefficient of 0.44 and the $t-$ statistic of 5.24 at a significance level of 0.01 . Therefore, the fourth hypothesis was confirmed. In the fifth hypothesis, there was a positive and significant relationship between customer satisfaction and customer service with the path coefficient of 0.37 and the t-statistic of 4.33 at a significance level of 0.01 . The fifth hypothesis was also accepted. According to the sixth hypothesis, a positive and significant relationship was found between customer trust and loyalty with the path coefficient of 0.26 and the t-statistic equal to 2.33 at the significance level of 0.05 . As a result, the sixth hypothesis was confirmed. Moreover, a positive and significant relationship was found between customer satisfaction and customer loyalty with a path coefficient of 0.57 and the t-statistic of 4.19 at a significance level of 0.01 ; thus the seventh hypothesis was also accepted. According to the eighth hypothesis, there was an inverse and negative relationship between the perceived risk and customer loyalty with the path coefficient of -0.18 and the t-statistic of -3.49 at a significance level of 0.01 . Therefore, the eighth positive and significant relationship was found between the relative advantages and customer loyalty with the path coefficient of 0.67 and the t-statistic of 6.87 at a significance level of 0.01. Consequently, the ninth hypothesis was confirmed.

\section{Discussion}

Hypothesis 1: The effect of usability on customer trust in Thakur's model (2014) was confirmed. Most users of mbanking in the study conducted in India by Thakur (2014) were involved in the field of financial services, and a few users were self-employed. This suggests that the reason why some people were more aware of the financial and banking fields than others was that they could better comprehend the issue of m-banking and their trust level was higher than that of others. In the study, most users were employed, which makes it likely that part of them were involved in banking affairs. Given that individuals with a diploma in the study constituted a relatively small number, it is appropriate to design the m-banking UI in such a way that it can be used easily by individuals possessing all levels of knowledge.

Hypothesis 2: The impact of usability on customer service in Thakur's model (2014) was rejected. The definitions of customer service and usability suggest that this is inevitable because usability originating from the ease of use and customer service implies the service provider's assistance and continuous support for the customers.

Hypothesis 3: The effect of usability on customer satisfaction in Thakur's model (2014) was confirmed. Due to the age limitation in Thakur's study (2014), in which most users were aged 20 to 30 years old, it was determined that younger people would find using m-banking easier, and the software features of m-banking could have a significant impact on their satisfaction. This was consistent with the results of previous research, such as studies by Flavian, Guinaliu, and Gurrea (2006). In one European study conducted in Spain by Casalo et al. (2008), similar limitations were encountered with regards to age. The majority of users were aged 25 to 34 years old. In the current study, the largest number of users were also in the age group of 25 and 35 years old. Considering the fact that individuals aged 40 years and older were in the lowest numbers of mbanking users, Shahr Bank can design an appropriate UI and implement an appropriate level of image zoom (appropriate fonts) to gain the satisfaction of this age range.

Hypothesis 4: The impact of customer service on customer trust in Thakur's model (2014) was not accepted due to the small sample size of 433 in the context of a country like India with a very large population. In this case, the causes cannot be properly explored. Nonetheless, this suggests that in terms of m-banking among the individuals in the sample of Thakur's study (2014), customer services are not provided (that is, support units are not very responsive to the customers) or customer service does not lead to customer trust.

Hypothesis 5: The effect of customer service on customer satisfaction in Thakur's model (2014) was confirmed. The distinction between satisfaction and trust is clear. In Thakur's study (2014), the effect of customer 
service on customer trust was not confirmed, but its effect was confirmed on customer satisfaction. This can prove that, in the sample in Thakur's study (2014), the issues of trust and customer service are not related to each other, while the inefficient responsiveness of the support units is not associated with this problem. This may partly reflect the difference between Hindi and Iranian societies, as the current study suggests that satisfaction and trust can be complementary.

Hypothesis 6: The impact of trust on customer loyalty in Thakur's model (2014) was confirmed. These findings indicate that trust is a prerequisite for loyalty. These findings are in agreement with the results obtained by Schaupp and Belanger (2005). Although they achieved these results in the US, and there are obvious differences between Western societies and Iran, similar results have been obtained in this case. It should be noted that in our study, employed persons are the most common users of mbanking, and their use is likely higher because of their busy work schedules, which leads to increased use of electronic services. Consequently, the more the trust in this group increases, the more their loyalty goes up.

Hypothesis 7: The effect of customer satisfaction on customer loyalty in Thakur's model (2014) was accepted. While the findings of Thakur (2014) revealed that both satisfaction and trust affect loyalty, the effect of trust on loyalty is negligible. The possible explanation for this paradox may be that trust is a prerequisite for customer's inclination to use and test the services. Where trust is absent in such circumstances, which are based on the ability of the bank to transfer and receive money securely and to keep personal information confidential, customers are not likely to accept such a communications channel (i.e. m-banking).

Hypothesis 8: The effect of perceived risk on customer loyalty in Kabir's model (2013) was confirmed. This study was conducted in Bangladesh, which neighbours India and whose population is mostly Muslim. Therefore, given the cross-cultural studies of Hofstede, the results of this investigation can be considered more closely than those of the Western studies. According to the results of Kabir (2013), less the social risk index, perceived risk has a negative impact on the use of m-banking and customer loyalty. Lee's study (2009), which was conducted in Taiwan, revealed a significant relationship between $\mathrm{m}$ banking use and the indicators of time risk, social risk, and financial risk. However, there was no relationship between security risk and the use of mobile banking. In our study, there is an implication that people aged 40 years and older are not as likely to take risks as young people. Consequently, they make less use of m-banking services. Therefore, these users require a very secure network.

Hypothesis 9: The effect of relative advantages on customer loyalty in Kabir's model (2013) was confirmed. Relative advantages can lead to customer loyalty, and this was confirmed in this investigation. In our research, there was a small number of students and unemployed individuals compared to the number of employed individuals that use mobile banking, which is likely to be appropriate (because the former group does not need extensive banking services). However, self-employed people are a small number compared to the employed persons. In this case, it is necessary to discuss the relative advantages because the explanation of time and cost savings for the benefit of these people can lead to an establishment of individuals that are loyal to these services.

As for the limitation of this research, it is necessary to mention that similarities and differences in the results of the hypotheses in this study and other research hypotheses have been certainly achieved. However, this is not a criterion for creating value. Moreover, due to the differences in the dimensions of time, geography, and the type of sampling, a comprehensive analysis cannot be achieved. Therefore, the acceptance or rejection of any hypothesis should be considered within the structure of the particular research in view of the circumstances of time and place.

Possibly, there are other effective variables involved in the use of m-banking by customers and their loyalty, such as the impact of culture and other demographic variables.

The research could include other factors affecting mbanking customer loyalty in other banks. It could also extend this study to a larger circle of branches and cities in Iran and make a comparison with the findings of the current study.

Studies on the factors affecting customer loyalty to other e-banking services such as internet banking, etc.

Use of other models presented in the context of factors affecting m-banking customer loyalty.

Studies on newer topics of e-banking such as USSD (Unstructured Supplementary Service Data) or a new service such as VTM (Virtual Teller Machine).

\section{Conclusion}

It is necessary to mention that similarities and differences in the results of the hypotheses in this study and other research hypotheses have certainly been achieved, but this is not a criterion for creating value. Moreover, due to the differences in the dimensions of time, geography, and the type of sampling, a comprehensive analysis cannot be achieved. Therefore, the acceptance or rejection of any hypothesis should be considered within the structure of that research, given the circumstances of time and place.

Based on the results of this study, various strategies can be shaped to facilitate the work of managers and directors of Shahr Bank to provide better electronic services, especially in the field of $\mathrm{m}$-banking services. Firstly, customer access would be much easier, which at the moment requires that the marketing managers of these institutions develop an appropriate marketing program to achieve their desired goals systematically. One of the critical parts of any marketing plan is defining target markets and ways of approaching them. In this respect, the findings of this study can dramatically help the managers of Shahr Bank.

Banks should focus on the design of a UI with increased usability and usefulness. Among the numerous factors considered for the usability of m-banking, the lack of software defects and elegant templates for the pages of mbanking is of the utmost importance. Moreover, according to the literature and previous research, we recommend that easy and convenient UI is created and organized. Due to the small screen and a lack of possibility to place large amounts of information and tutorials of various transactions, the UI must be simple and intuitive. 
Establishing appropriate support services and making them responsive for 24 hours a day lead to higher trust in $\mathrm{m}$ banking.

Perceived quality of customer service has a significant impact on overall satisfaction. These findings imply that the inability to provide customer service related to contact points (especially call centres) and inability to provide accurate information can lead to dissatisfaction, which is in agreement with the findings of Ganguli and Roy (2011). The service provider must continually provide its agents with updated training and invest in this area to achieve customer satisfaction.

In order to increase trust through enhanced customer service, customer loyalty needs to be enhanced. Moreover, IT infrastructure, which is pivotal to m-banking, enhances customer awareness and trust. Customers need to be properly assured that m-banking error rates are at the minimum.

Since customers' high trust leads to increased loyalty, their loyalty increases their satisfaction. Therefore, there is a need to pay attention to customers' needs and to create a variety of m-banking services to increase customer satisfaction and turn them into loyal customers.

Perceived risk, including time risk, performance risk, security risk, social risk, and financial risk, are the factors that can have negative effects on customer loyalty. Types of perceived risks in accordance with their definitions make customers hesitant about using m-banking. Therefore, banks can provide continuous support and further information about m-banking to eliminate doubts in this regard and encourage customers to be loyal.

Usefulness or relative advantages refer to the level of various benefits that consumers acquire from a new product or service compared to the alternatives. Comparative advantages are one of the essential factors in determining the application of innovation. According to the results of this study, relative advantages are factors in the use of m-banking services. Therefore, marketing authorities should be able to create a variety of benefits of using this technology compared to other technologies as well as a referral system for their customers (especially non-users) to drive them to use this technology. If a bank customer does not differentiate between going to the bank in person and using m-banking, this reflects a lack of relative advantages in this technology compared to traditional banking. Considering the cost and time savings that come with the use of m-banking, it should be communicated to the customer that m-banking can be useful and offer relative advantages in these two areas. An increase in the response speed within the m-banking service can play an essential role in creating loyalty to this service by being extremely welcome with regards to the value of time in a busy city like Tehran.

\section{References}

Aldas-Manzano, J., Ruiz-Mafe, C., Sanz-Blas, S., \& Lassala-Navarre, C. (2011). Internet banking loyalty: Evaluating the role of trust, satisfaction, perceived risk and frequency of use. The Service Industries Journal, 31(7), 1165-1190. https://doi.org/10.1080/02642060903433997

Alonso-Dos-Santos, M., Soto-Fuentes, Y., \& Valderrama-Palma, A.V. (2020). Determinants of Mobile Banking Users' Loyalty. Journal of Promotion Management, pp. 1-19. https://doi.org/10.1080/10496491.2020.1729312

Arcand, M., PromTep, S., Brun, I., \& Rajaobelina, L. (2017). Mobile banking service quality and customer relationships. International Journal of Bank Marketing, 35(7), 1068-1089. https://doi.org/10.1108/IJBM-10-2015-0150

Bitner, M. J. (1992). Services capes: the impact of physical surroundings on customers and employees. Journal of Marketing, 56 (2), 57-71. https://doi.org/10.1177/002224299205600205

Burgers, A., de Ruyter, K., Keen, C. \& Streukens, S. (2000). Customer expectation dimensions of voice-to-voice service encounters a scale-development study. International Journal of Service Industry Management, 11(2), 142-161. https://doi.org/10.1108/09564230010323642

Burrell, G. \& Morgan, G. (1994). Sociological Paradigms and Organisational Analysis, Heinemann, London.

Coker, B. (2013). Antecedents to website satisfaction, loyalty, and word-of-mouth. Journal of Information Systems and Technology Management, 10(2), 209-218. https://doi.org/10.4301/S1807-17752013000200001

Davidaviciene V., Davidavicius S., \& Kausinis J. (2019). Consumer dissatisfaction structure - e-logistic perspective: Lithuania case. International journal of learning and change. Geneva: Inderscience Enterprises Ltd. 11(3), $237-251$. https://doi.org/10.1504/IJLC.2019.103328

Davidaviciene, V., Pabedinskaite, A., \& Davidavicius, S. (2017). Social Networks in B2B and B2c Communication. Transformations in Business and Economics 16(1), 69-84.

Davis, F. D. (1989). Perceived usefulness, perceived ease of use, and user acceptance of information technology. MIS Quarterly, 13(3), 319-340. https://doi.org/10.2307/249008

Eid, M. I. (2011). Determinants of E Commerce Customer Satisfaction, Trust, and Loyalty in Saudi Arabia. Journal of Electronic Commerce Research, 12, 78-93.

Featherman, M., \& Fuller, M. (2002). Applying TAM to e-services adoption: the moderating role of perceived risk. In: Proceedings of the 36th Hawaii international conference on system sciences. https://doi.org/10.1109/ HICSS.2003.1174433 
Ahmad Esmaeili, Iman Haghgoo, Vida Davidaviciene, Ieva Meidute-Kavaliauskiene. Customer Loyalty in Mobile ...

Flavian, C., Guinaliu, M., \& Gurrea, R. (2006). The role played by perceived usability, satisfaction and consumer trust on website loyalty. Information \& Management, 43(1), 1-14. https://doi.org/10.1016/j.im.2005.01.002

Ganguli, S., \& Roy, S. (2011). Generic technology-based service quality dimensions in banking. The International Journal of Bank Marketing, 29(2), 168-189. https://doi.org/10.1108/02652321111107648

Geyskens, I., Steenkamp, J. B. E. M., \& Kumar, N. (1999). A meta-analysis of satisfaction in marketing channel relationships. Journal of Marketing Research, 36(2), 223-238. https://doi.org/10.2307/3152095

Ho, C. T. B., \& Lin, W. C. (2010). Measuring the service quality of internet banking: scale development and validation. European Business Review, 22(1), 5-24. https://doi.org/10.1108/09555341011008981

Kabir, M. R. (2013). Factors Influencing the Usage of Mobile Banking : Incident from a Developing Country. World Review of Business Research, 3(3), 96-114.

Karimi, A. M. R., Esmaeili, A., Sepahvand, A., \& Davidaviciene, V. (2018). The Effect of Customer Equity Drivers on Word-ofMouth Behavior with Mediating Role of Customer Loyalty and Purchase Intention, Inzinerine Ekonomika-Engineering Economics, 29(2), 236-246. https://doi.org/10.5755/j01.ee.29.2.17718

Kim, K., \& Prabhakar, B. (2000). Initial trust, perceived risk, and the adoption of internet banking, Proceedings of the TwentyFirst International Conference on Information Systems. Association for Information Systems Atlanta, pp. 537-543.

Laukkanen, T. (2005). Comparing Customer Value Creation in Internet and Mobile banking, Computer Society. Conference: Mobile Business, 2005. ICM-BANKING 2005. https://doi.org/10.1109/ICM-BANKING.2005.28

Laukkanen, T. (2016). Consumer adoption versus rejection decisions in seemingly similar service innovations: The case of the Internet and mobile banking. Journal of Business Research, 69(7), 2432-2439. https://doi.org/10.1016/j.jbusres. $\underline{2016.01 .013}$

Lee, M. (2009). Factors influencing the adoption of internet banking: An integration of TAM and TPB with perceived risk and perceived benefit. Electronic Commerce Research and Applications, 8(3), 130-141. https://doi.org/10.1016/j.elerap. 2008.11.006

Liebana Cabanillas, F., Alonso Dos Santos, M., Soto Fuentes, Y., \& Valderrama Palma, V. A. (2017). Unobserved heterogeneity and the importance of customer loyalty in mobile banking. Technology Analysis \& Strategic Management, 29(9), 10151032. https://doi.org/10.1080/09537325.2016.1262021

Lin, J., Xue, G., Fu, Y., \& Xu, L. (2018). Factors Affecting Consumers' Acceptance of e-Commerce Consumer Credit Service. International Journal of Information Management, 40, 103-10. https://doi.org/10.1016/ j.ijinfomgt. 2018.02.002

Low, Y. M., Goh, C. F., Tan, O. K., \& Rasli, A. (2017). Users loyalty towards Mobile Banking in Malaysia. The Journal of Internet Banking and Commerce, 1-12.

Luarn, P., \& Lin, H. (2005). Toward an understanding of the behavioural intention to use mobile banking. Computers in Human Behavior, 21(6), 873-891. https://doi.org/10.1016/j.chb.2004.03.003

Mladenovic, D., \& Krajina, A. (2020). Knowledge sharing on social media: state of the art in 2018. Journal of Business Economics and Management, 21(1), 44-63. https://doi.org/10.3846/jbem.2019.11407

Mohammadi, H. (2015). A study of mobile banking loyalty in Iran. Computers in Human Behavior, 44, 35-47. https://doi.org/10.1016/j.chb.2014.11.015

Mokhtar, S. A., I. HIdayat-ur-Rehman, \& Katan, H. (2017). Mobile Banking Adoption: The Impacts of Social Influence, Ubiquitous Finance Control and Perceived Trust on Customer Loyalty, Sci.Int. (Lahore), 29(4), 829-836.

Morgan, R. M., \& Hunt. S. D. (1994). The commitment-trust theory of relationship marketing. Journal of Marketing, 58(3), 2038. https://doi.org/10.1177/002224299405800302

Nexhmi, R. (2004). The Impact of The relational Plan on Adoption of Electronic Banking. Journal of Services Marketing, $20-42$.

Nielsen, J., \& Hackos, J. T. (1993). Usability Engineering, Academic Press, San Diego, CA.

Palamidovska-Sterjadovska, N., \& Ciunova-Shuleska, A. (2017). An Integrated Model of Customer Loyalty in the Macedonian Mobile Service Market. E+M Ekonomie a management, 20(2), 199-215. https://doi.org/10.15240/ tul/001/2017-2-015

Pikkarainen, T., Pikkarainen, K., Karjaluoto, H., \& Pahnila, S. (2004). Consumer acceptance of online banking: An extension of the technology acceptance model. Internet Research, 14(3), 224-235. https://doi.org/10.1108/10662240410542652

Puriwat, W., \& Tripopsakul, S. (2017). The impact of e-service quality on customer satisfaction and loyalty in mobile banking usage: case study of Thailand. Polish Journal of Management Studies, 15(2), 183-193. https://doi.org/10.1 7512/pjms.2017.15.2.17 
Raudeliuniene, J., Davidaviciene, V., Tvaronaviciene, M., \& Jonuska, L. (2018). Evaluation of Advertising Campaigns on Social Media Networks. Sustainability, 10(973), 1-14. https://doi.org/10.3390/su10040973

Rizwan, R. A., Vveinhardt, J., \& Streimikiene, D. (2017). Interactive digital media and impact of customer attitude and technology on brand awareness: evidence from the south Asian countries. Journal of Business Economics and Management, 18(6), 1115-34. https://doi.org/10.3846/16111699.2017.1400460

Sabaityte, J., Davidaviciene, V., Strakova J., \& Raudeliuniene, J. (2019). Decision tree modelling of e-consumers' preferences for internet marketing communication tools during browsing. E\&M Economics and Management = E\&M Ekonomie a management, 22(1), 206-221. https://doi.org/10.15240/tul/001/2019-1-014

Schaupp, L. C., \& Belanger, F. (2005). A conjoint analysis of online consumer satisfaction. Journal of Electronic Commerce Research, 6(2), 95-111.

Sekhon, H., Ennew, C., Kharouf, H., \& Devlin, J. (2014). Trustworthiness and trust: influences and implications. Journal of Marketing Management, 30(3/4), 409-430. https://doi.org/10.1080/0267257X.2013.842609

Sekhon, H., Lifen Zhao, A., Koenig-Lewis, N., Hanmer-Lloyd, S., \& Ward, P. (2010). Adoption of internet banking services in China: is it all about trust? International Journal of Bank Marketing, 28(1), 7-26. https://doi.org/10.1108/ $\underline{02652321011013562}$

Shaikh, A. A., \& Karjaluoto, H. (2015). Mobile banking adoption: A literature review. Telematics and Informatics, 32(1), 129142. https://doi.org/10.1016/j.tele.2014.05.003

Shankar, A., \& Jebarajakirthy, C. (2019). The influence of e-banking service quality on customer loyalty. International Journal of Bank Marketing, 37, 1119-1142. https://doi.org/10.1108/IJBM-03-2018-0063

Shankar, A., Jebarajakirth, C., \& Ashaduzzaman, Md. (2020). How do electronic word of mouth practices contribute to mobile banking adoption?, Journal of Retailing and Consumer Services, 2, 1-14. https://doi.org/10.1016/j. jretconser.2019.101920

Sujeong, Ch. (2018). What Promotes Smartphone-Based Mobile Commerce? Mobile-Specific and Self-Service Characteristics, Internet Research, 28(1), 105-22. http://www.emeraldinsight.com/doi/10.1108/IntR-10-2016-0287. https://doi.org/10.1108/ IntR-10-2016-0287

Sun, Y., Wang, M., \& Wang, N. (2015). Technology Leadership, Brand Equity, and Customer Loyalty in Mobile Banking: Moderating Role of Need for Uniqueness. Technology, 12, 13-2015.

Swan, J. E., \& Oliver, R. L. (1989). Postpurchase communications by consumers. Journal of Retailing, 65(4), 516-533.

Teo, T. S. H. (2006). To buy or not to buy online: adopters and non-adopters of online shopping in Singapore. Behaviour Information Technology, 25(6), 497-509. https://doi.org/10.1080/01449290500256155

Thakur, R. (2014). What keeps mobile banking customers loyal ?, International Journal of Bank Marketing, 32(7), 628-646. https://doi.org/10.1108/IJBM-07-2013-0062

Torabi, M. (2009). Factors affecting the use of electronic services of mobile banking by customers (the case of Tejarat Bank). Supervisor: Mohammad Taghi Taghavi Fard. Master's Thesis in IT management, Allameh Tabatabaii University (In Pesian).

Van Esterik-Plasmeijer, P. W., \& van Raaij, W. F. (2017). Banking system trust, bank trust, and bank loyalty. International Journal of Bank Marketing, 35(1), 97-111. https://doi.org/10.1108/IJBM-12-2015-0195

Verhagen, T., Meents, S., \& Yao-Hua, T. (2006). Perceived risk and trust associated with purchasing at electronic marketplaces. European Journal of Information Systems, 15(6), 542-556. https://doi.org/10.1057/palgrave.ejis. 3000644

Vo, L. V., Le, H. T. T., Le, D. V., Phung, M. T., Wang, Y. H., \& Yang, F. J. (2017). Customer satisfaction and corporate investment policies. Journal of Business Economics and Management, 18(2), 202-223. https://doi.org/10.3846/ $\underline{16111699.2017 .1280845}$

Wan, W. W. N., Luk, C. L., \& Chow, C. W. C. (2005). Customers' Adoption of Banking Channels in Hong Kong. International Journal of Bank Marketing, 23(3), 255-272. https://doi.org/10.1108/02652320510591711

Wu, J., \& Wang. S. (2005). What drives mobile commerce?: An empirical evaluation of the revised technology acceptance model. Information \& Management, 42(5), 719-729. https://doi.org/10.1016/j.im.2004.07.001

Yeh, Y.S., \& Li, Y. M. (2009). Building trust in m-commerce: contributions from quality and satisfaction. Online Information Review, 33(6), 1066-1086. https://doi.org/10.1108/14684520911011016

Yoon, S. J., \& Kim, J. H. (2000). An empirical validation of a loyalty model based on expectation disconfirmation. Journal of Consumer Marketing, 17(2), 120-136. https://doi.org/10.1108/07363760010317196

Zhou, T. (2011). An empirical examination of initial trust in mobile banking. Internet Research, 21(5), 527-540. https://doi.org/10.1108/10662241111176353 
Zhou, T. (2018). Examining users switch from online banking to mobile banking. International Journal of Networking and Virtual Organizations, 18(1), 51-66. https://doi.org/10.1504/IJNVO.2018.090675

\section{Authors' biographies}

Dr. Ahmad Esmaeili Ph.D. in industrial management. As a social science researcher, he works at National Level Policy Making in National Research Institute for Science Policy of Iran, part-time professor in Allameh Tabataba'i University, Iran, Tehran, and freelancer in various national and corporate level research projects. He has published papers with a focus on supply chain management, multi-criteria decision-making, service operations management, and strategic management. He is a reviewer for various national and international journals. His research interests include decision-making theories, supply chain management, qualitative research methods, sustainability issues in supply chain management, quality management, logistics, and the service industry.

Iman Haghgoo has finished his B.A. in industrial engineering and M.A. in Business Administration. He has worked as a project manager in various market-related issues as an analyst and R\&D manager. He is now working as a business developer and R\&D manager. His research interests include customer relations, aftermarket service, marketing, and Fintech.

Prof. dr. Vida Davidavičienė has 20 years of academic and scientific experience. Her research interests are ICT development's influence on society, business, and economics. She is a member of the scientific comities of several scientific journals and international scientific conferences. She is a member of the management science board in Vilnius Tech, Chair of Business Management and Business Logistic study programs committees. Vida Davidaviciene is an Expert at the Research Council of Lithuania and MITA (Science, Technology and Innovation Agency) since 2018. Since 2017 members of the Lithuanian Standards Board Technical Committee LST TK 90 Human Resources and Knowledge Management.

Ieva Meidutè-Kavaliauskienė has about 15 years lectures experience (taught such courses as logistic, transport management, supply chain management, warehouse logistics and operations management). Her research interests are related to logistics and supply chain management, formation and evaluation of strategic decisions, decision making. She is an author of more than 50 scientific publications indexed in Web of Science, Scopus, Ebsco, Emerald, and other databases, published several monographs and textbooks. She is a member of the scientific committees of several scientific journals and international scientific conferences. ORCID ID: orcid.org/0000-0003-0435-7632

The article has been reviewed.

Received in February 2020; accepted in February 2021.

This article is an Open Access article distributed under the terms and conditions of the Creative Commons Attribution 4.0 (CC BY 4.0) License (http://creativecommons.org/licenses/by/4.0/). 